\title{
Nafta at 25: the End or Just the Beginning?
}

Jordan Bankhead

On the hundredth day of his presidency, Donald Trump was prepared to withdraw from the North American Free Trade Agreement (NAFTA), signed into law 23 years earlier by Bill Clinton on January 1, 1994. Trump's fiery America-first advisor Steve Bannon urged him to make good on campaign promises in which he pledged to quit NAFTA. Recounting his deliberations over NAFTA, Trump said, "I was all set to terminate (NAFTA)" because it was "a total disaster" and "one of the worst deals ever". ${ }^{1}$ As it happened, Trump did not cancel the agreement on day 100 of his presidency and is unlikely to do so. The reason for this uncharacteristic restraint on the part of Trump can be explained by the advice of his commerce secretary Wilbur Ross and Agriculture Secretary Sonny Purdue. Both advisors in a West Wing meeting just prior to Trump's decision told the president not to cancel NAFTA because American farmers, the domestic oil industry, and the businessmen key to Trump's victory would suffer grievous economic harm if the agreement was terminated. After being persuaded by this advice, Trump spoke to the leaders of Canada and Mexico and said he had been motivated by them to give negotiations on NAFTA a chance. In fact, the cost of quitting the largest free trade agreement in the world would have been too high and Trump knew this would jeopardize his chances of reelection. Voters primarily vote with their pocket books, and despite the cries of environmentalists, labor activists, and his own blue collar voter base, Trump is unlikely to cancel NAFTA and will accept a tweaked version of the historic trade agreement that joined a developing country with a developed country in a free trade agreement for the first time.

The case of the durability of NAFTA, despite the attacks of a populist president with little regard for collateral damage to trade partners, political opponents, the press, or democratic institutions, demonstrates that once a high level of economic integration is achieved by these agreements, undoing them is very difficult and costly. The unfolding saga of Brexit in Europe illustrates a similar principle. A wholesale divorce from the EU by Great Britain would almost certainly lead to economic catastrophe for that country, at least in the short to medium term. This suggests the UK and Europe will find a happy medium to protect both sides, most likely leaving free trade flowing because of the economic damage the undoing decades of economic integration would do. Because the case of the UK may be a special case based on its unique history as an "offshore balancer" and an island nation, it is unlikely Brexit will lead to further fracturing of the EU. On the contrary, it appears Europe is moving toward ever closer union, presently debating the merits of a common foreign and security policy. Leaders of Europe like Chancellor Merkel and President Macron may even feel emboldened to pursue greater European integration given the absence of Great Britain from the negotiating table. And with a renewed commitment to fulfill the socalled third pillar of the EU on security, Europe may be one crucial step closer to full-blown federation.

As global economic competition grows with the rise of China, the United States will find 
incentives to rein in its more reckless behavior in fomenting trade war with allies in Europe and North America. Signs of a thaw in trade relations between Europe and the United States are already evident with the public statement from Trump and EU Commission chief JeanClaude Juncker to not impose additional tariffs and start negotiations on trade cooperation. The leaders issued a joint statement pledging to" work together toward zero tariffs, zero nontariff barriers, and zero subsidies on non-auto industrial goods". ${ }^{2}$ The reason for this détente between Europe and the US can be explained by mutual economic gain and a common political culture. On the first point, the US stands to gain by diversifying its trade away from China by exporting more liquified natural gas (LNG) and soybeans to Europe. This bilateral trade relationship also aids Europe strategically by making European countries less dependent on Russian natural gas. Strengthening the case for NAFTA's durability, US Trade Representative (USTR) Lighthizer testified before a Senate appropriations committee on NAFTA and said he expects a NAFTA agreement to come soon. Lighthizer also said he expected China to be a longer term problem because that nation continues to "take over" American technology and they need to be deterred by a proactive American trade policy. ${ }^{3}$

The new paradigm of economic nationalism launched by the United States under Trump and other countries like Italy and Great Britain shows no sign of abating any time soon. In fact, the dark side of globalization and free trade has recently caused public opinion to favor more protectionism. The drum beat of doomsday scenarios of corporate malfeasance, environmental destruction, and labor abuse caused by international trade agreements may finally be gaining traction in national electorates. On the $20^{\text {th }}$ anniversary of the NAFTA agreement, this opposition was manifested in the release of a case study by the
NGO Public Citizen on"investor-state attacks on public interest policies." 4 The report argued that dispute settlement bodies set up by NAFTA favored corporate and investor rights over local environmental, public health, and labor rights protected by the states. In effect, these dispute-settlement bodies, composed of three corporate lawyers predisposed to corporate interests and interpreting businessfriendly NAFTA provisions, were helping multinational corporations exploit local citizens. Of course, the article prescribed a roll back of the NAFTA agreement to right these wrongs, but neglected the possibility of reforming and making the NAFTA agreement more democratic and responsive to local citizens' interests. The national backlash against trade agreements and other international economic institutions that suffer a democratic deficit can also be seen in the wave of populist nationalist leaders coming to power around the world. Of course, this is not happening in a vacuum, as authoritarian Russia has an interest in western nations dissolving historic alliances like NATO, and the unraveling of post-war international economic institutions like the WTO, the IMF, and the World Bank.

Because the nation-state is still deemed by most as the only force capable of protecting the interests of people abused by global corporations and global elites, the prospects for more international cooperation may seem bleak. This view is reinforced by the daily assault on international and domestic political institutions by populist leaders, who use social media to keep the public's attention to divide and conquer. Donald Trump takes to Twitter to vent against his political opponents, and other leaders are doing the same. The smartphone has made news instantaneous and increased the rate of uptake of world events by the general public. This has led to a fracturing of public opinion, and with it, a 
division of the public square into competing and more extreme political fractions. Where this leads cannot be completely predicted, but more likely than not, the stresses on the status quo will lead to reform and ultimately benefits for the world's citizens. There is even a chance that by attacking international institutions like the EU, NAFTA, the WTO and others, nationalist leaders will provoke a productive debate about how to make those institutions more democratic and responsive to real people's needs and concerns. This is the promise of the current era of pessimism and backlash to globalization. Just as terrorism ultimately will fail as a prescription to the problems of groups whose views are not widely shared, so too will nationalism and isolationism fail in the long run. These ideologies were discredited as appropriate policy prescriptions for at least the past one hundred years. Predicting the future of NAFTA, the EU, and ultimately the UN, therefore, it can be surmised that these institutions will prove more formidable than their attackers anticipate. As William Faulkner famously mused upon accepting the Nobel peace prize, not only will international institutions survive, but they will endure. But political legitimacy ultimately rests with the people, and as new technologies lead to more transparency and openness, the seemingly invincible walls of sovereignty possessed by the nation-state will give way. The precedent for this is the history of human progress, which typically lags economic innovation but ultimately does catch up for the benefit of all the people.

\footnotetext{
${ }^{1}$ The Washington Post, April 27, 2017, Parker, Rucker, Paletta, and DeYoung, https://www.washingtonpost.com/politics/i-was-all-set-to-terminate-inside-trumpssudden-shift-on-nafta/2017/04/27/0452a3fa-2b65-11e7-b605-33413c691853_story.html?noredirect=on\&utm_term=.5fb445aaecde

${ }^{2}$ BBC News, July 26, 2018, Trump and EU's Juncker pull back from all out trade war, https://www.bbc.com/news/world-us-canada-44961560

${ }^{3}$ Marketwatch, July 26, 2018, https://www.marketwatch.com/story/lighthizer-reports-progress-on-nafta-says-china-to-be-long-term-problem-2018-07-26

${ }^{4}$ https://www.citizen.org/sites/default/files/egregious-investor-state-attacks-case-studies_4.pdf
} 